\title{
Johor Military Force (Jmf): The Only Royal Security Force in Malaysia
}

\author{
Muhaymin Hakim bin Abdullah ${ }^{\mathrm{a}}$, Khairul Azman bin Mohd Suhaimy ${ }^{\mathrm{b}}$, Md Akbal bin Abdullah ${ }^{\mathrm{c}}$ and \\ Zahrul Akmal bin Dalimin ${ }^{\mathrm{d}}$ \\ a,b,c,d \\ Centre for General Studies and Co-Curricular, Universiti Tun Hussein Onn Malaysia
}

Article History: Received: 11 January 2021; Accepted: 27 February 2021; Published online: 5 April 2021

\begin{abstract}
The unique feature of the state of Johor that distinguishes it from other states in Malaysia is the existence of its own royal security force known as the Johor Military Force (JMF) or 'Askar Timbalan Setia Negeri Johor' (ATSN). The JMF was established in 1886 by the late Maharaja Abu Bakar as contained in the Loyalty Agreement signed by the Johor state government with the British government at the Colonial Office, London. The JMF once served as a state defense fortress besides assisting the police in ensuring security in the state of Johor. With the inclusion of Johor into the Federation of Malaya, JMF has remained until now but its role has shifted to the security of the family of Sultan of Johor and its assets only. Now, after a century, today's generation is less knowledgeable about the role and historical value that exists with this JMF team that needs to be known and preserved. This article aims to provide an explanation on the existence of the JMF team in more depth to the current and future generations. Library research was used with reference to the printed documents housed in the National Archives of Johor Branch and the Johor Royal Museum in addition to the research on digital media through the 'History Channel' documentary. The results of the study show that the existence of this team needs to be fully preserved and further research needs to be done thoroughly to ensure that its historical value continues to be preserved from time to time.
\end{abstract}

Keywords: Johor Military Force, JMF, Royal Security Force, Historical of Johor

\section{Introduction}

In 1842 , the Government of Johor or the Johor Sultanate was handed over to the dynasty of Temenggong. Daeng Ibrahim was the first government of the Temenggong dynasty. He died on 1 February 1862 . He was replaced by his son named Encik Wan Abu Bakar who used the title Dato' Temenggong Abu Bakar and continued his ambition to strengthen the government under the Temenggong dynasty (Fawzi Basri, 1988). To achieve this ambition, Dato' Temenggong Abu Bakar with his efforts and leadership created a good relationship with the British government in the Straits Settlements and made a visit to England for the first time in 1866 to further strengthen the relationship between the Government of Johor and the Government of British. On 11 December 1885, a Loyal Treaty between the Johor state government and the British government was signed at the Colonial Office, London between Maharaja Abu Bakar and the British representative, which was witnessed by some officials from both governments. One of the agreements in the Loyal Treaty was that the Johor Government must maintain the security of the state of Johor and Singapore. After the signing of the Loyal Treaty, Maharaja Abu Bakar requested to set up the JMF to act as the security force for the protection of the state and the Government of Johor. Now, after 135 years since its establishment, the current young generation, especially non-Johor-born children, is unaware of the historical value of the JMF that needs to be preserved. This article aims to give the information on the history of the establishment of JMF according to the era of the Modern Johor Sultanate.

\section{Methodology}

To understand the role of the JMF since its inception until now, case studies using historical research methods are made through library research with reference to secondary sources related to the establishment of the JMF which are the original printed documents such as books, and reports available at the National Archives of Johor Branch and the Royal Johor Museum. Research on digital media through the 'Historical Channel' which produced documentaries on the history of the JMF and held interview sessions with some of the main figures was refined. Among the main figures in the documentary were the Sultan of Johor, Sultan Ibrahim Ibni Sultan Iskandar as the Commander of the JMF and Tunku Mahkota of Johor (TMJ), Tunku Ismail Ibni Sultan Ibrahim as the Commanding Officer of the JMF. In addition, the documentary program also interviewed several other dignitaries including YB Dato' Dr. Abdul Rahim bin Ramli, Yang DiPertua Majlis Jumaah DiRaja Johor, and several members of the JMF who have served for a long time and those who have recently served. All the interview data from the documentary were collected and analyzed to achieve the objectives of this study.

\section{JMF the Only Royal Security Force in Malaysia}

Once upon a time, the integrity of a royal institution was often challenged by some extremists and the involvement of politicians, which for example, happened in the late 19th century in Thailand (Duncan, 2006) and Canada in this century (Damon, 2015). Nowadays, royal institutions are more vulnerable to cyber threats expressed by netizens. In fact, there are people who still do not know about the existence and role of this institution, especially in this country, let alone at the global level. These people consider that the monarchy is a historical relic that no longer has important roles and serves only as a symbol of the customs of a nation. 
In most monarchical countries, the king is a symbol of the continuity and sovereignty of the country in addition to serving as the head of religion or the highest commander in the armed forces. For example, in the United Kingdom and the countries under its auspice, the Queen is the head of the Protestant Christian religion and is merely a symbol of sovereignty in national unity. The power to run the cabinet administration is given to the prime minister as well as the ministers and is headed by the Queen, but Her Majesty has no power in politics (Institute of Historical Research, 2019). In Malaysia, the Yang Di-Pertuan Agong (YDPA) is the Head of State who acts as the head of the Islamic religion and also as the Supreme Commander (Supreme Government) of the Malaysian Armed Forces. The Malaysian Government Administration also practices the doctrine of separation of powers, namely the division of power into several main branches of government including Executive power exercised by the cabinet headed by the Prime Minister, the legislature exercising the Legislative power, and the judiciary exercising the Judicial power (Bharuddin, 2016).

The YDPA is appointed every five years in a rotation among the Malay rulers of the nine states in Malaysia. There are two important elements in the Malaysian monarchical system, namely the position of the Sultan in each state which is inherited for generations and the position of the YDPA is chosen on a rotational basis (Ong Guan Sai, 2016). This monarchy system is assisted by the existence of the Conference of Rulers as a traditional institution that assists in the implementation of democracy where its role is also enshrined in the Federal Constitution (Abdul Aziz Bari, 2002).

However, among the Malay rulers, only the state of Johor has its own soldiers. The JMF was established in 1886 in its original name, which was 'Pasukan Setia Negeri'. The establishment of JMF was the will and the consent of the Sultan of Johor, Sultan Abu Bakar son of Raja Temenggong Tun Daeng Ibrahim as a security force which consisted of Malay children in order to maintain the security of Johor after it was recognized as an independent state by the Great Britain. The establishment of this team was also based on the Johor Government Loyal Agreement with the British Government that was signed on 11 December 1885 at the Colonial Office, London, by Frederick A. Stanley, Secretary of State of the British Colony and Sultan Abu Bakar. The signing ceremony was witnessed by Robert G.W. Herbet and Dato Seri Amar Diraja Abdul Rahman bin Dato Wan Andak. During the reigns of Sultan Abu Bakar and His Majesty's son, Sultan Ibrahim, the role of the JMF team was more focused on defense for the state besides assisting the police in ensuring security in the state of Johor. However, after Johor's entry into the Federation of Malaya, the JMF still continues to function until now, but its role is focused on the security of the family of Sultan of Johor and its assets only.

\section{The Role of the Modern Johor Sultanate to JMF}

On March 10, 1855, Sultan Ali - who was the Sultan of Johor at that time - had agreed to hand over the government and the state of Johor with certain conditions to Temenggong Daeng Ibrahim (Rahim Ramli, 2018). Since then, the administration of the Modern Johor Sultanate from the Temenggong dynasty began. Daeng Ibrahim was the first ruler of the Temenggong lineage who died on February 1, 1862 (Shaharom Husain, 1995). He was replaced by his son named Encik Wan Abu Bakar who wore the title Dato' Temenggong Sri Maharaja Abu Bakar and used the title Sultan in 1885. The reign of the Sultanate of Modern Johor who wore the title Sultan began with Sultan Abu Bakar Al-Khalil Ibrahim Shah ibni Temenggong Seri Maharaja Tun Daeng Ibrahim, the second was Sultan Ibrahim Al-Masyhur Ibni Sultan Abu Bakar, the third was Sultan Ismail Al Khalidi Ibni Sultan Ibrahim, the fourth was Al-Mutawakkil Alallah Sultan Iskandar ibni Sultan Ismail and now the fifth is Sultan Ibrahim ibni Sultan Iskandar Al-Haj.

\subsection{Era of Sultan Abu Bakar Ibni Temenggong Daeng Ibrahim (1886-1895)}

Sultan Abu Bakar was born on February 3, 1833 at the Old Palace, Teluk Belanga, Singapore. He ruled the state of Johor for nine years from 13 February 1886 to 4 June 1895 . His coronation ceremony was held on 29 July 1886. After the death of his father, he continued his ambition to strengthen the government under the Temenggong dynasty (Fawzi Basri, 1988). To achieve this, Dato' Temenggong Abu Bakar with his efforts and leadership formed good relations with the British government in the Straits Settlements and visited England for the first time in 1866 to further strengthen the relationship between the Johor and the British Governments. This good relationship continued until a 'Loyal Treaty' was made on 11 December 1885 between the Johor state government and the British government (Shaharom Husain, 1995).

After the agreement was signed, Sultan Abu Bakar ordered the establishment of the JMF army. Initially, the main role of this team was to help maintain internal peace and was placed under one unit of the Johor Police Force (Royal Abu Bakar Museum, 2016). The JMF was placed under the leadership of the Johor Police Commissioner Dato Sri Setia Raja Abdullah bin Tahir. The Johor Police Force was also established by Maharaja Abu Bakar before the arrival of the British Adviser to the state of Johor. This move was in line with the Johor modernization policy implemented by His Majesty Maharaja Abu Bakar. The Police Commissioner was a Malay who was appointed in 1882. In 1915, this position was taken over by a British officer to restructure the police force to break the military uprising that took place in Singapore (Royal Malaysia Police Museum, 2019).

The JMF started with about 60 members led by Syed Yahya Mohamed bin Nong. A Palace Guard team consisting of $20 \mathrm{Kabul}$ people was also established to control the security of the palace. Then, the police trial unit of this police force was turned into an Army (Infantry). Members of the Palace Guard unit were transferred to a 


\section{Dalimin $^{d}$}

new unit, namely the Cannon Forces unit while the vacancy in the Palace Guard unit was then replaced with the new members of Malay youths who wear red "songkok".

In the early stages of its establishment, the JMF was divided into three units, namely the Infantry Unit, the Cannon Unit, and the Palace Guard Unit. These three units were distinct from each other and were placed under the control of their own chief. For example, in 1890, the Infantry Unit - comprised of two companies, namely Company I and Company II - was placed under the supervision of Mohammad Allee bin Awang. The Cannon Unit was placed under the supervision of Lieutenant Tengku Ibrahim while the Palace Guard Unit was under the control of Lieutenant Abdul Ghafoor.

In 1887, the Military Department was established to manage this team. An officer in the Second Battalion of the Royal Army of the Southern Irish Division, Captain Newland was appointed as the Government Officer. Currently, the strength of the JMF team members is as many as 200 people. In early 1890, Tengku Mahkota Ibrahim joined the JMF team and held the rank of Lieutenant. A 'Bras Band' that he founded prior to the establishment of the JMF was merged into the JMF army under the 'Band Unit'. The band comprised of Malay children with a fellow teacher named Golistan Netherlands. In 1905, these three units were merged under a new name, the Johore Military Forces (JMF), and were placed under the supervision of Captain Newland. Sultan Abu Bakar died on 4 June 1895 at the age of 62.

\subsection{Era of Sultan Ibrahim Ibni Sultan Abu Bakar (1895-1959)}

Sultan Ibrahim was born on September 17, 1873 at the Bidadari Palace, Serangoon, Singapore. He ruled the state of Johor for 64 years from 7 September 1895 to 8 May 1959. His coronation ceremony took place on 2 November 1895. After the death of his father, the JMF was placed under his patronage for 64 years. He was actively involved in the JMF before he ascended the Johor State Government throne again (Fawzi Basri, 1988). During the reign of Sultan Ibrahim, he further strengthened the JMF by bringing in two British officers - Lieutenant Major Tompkin and Sergeant Major Claymore - to train the members of this force. Among the exercises conducted at that time were marching exercises, shooting, motto training, and wireless signals. The role of the JMF team was expanded and the team was often involved in military operations and training with the British regiment in Singapore. Many reforms have been made to this team including the establishment of a volunteer team and the expansion of the number of its members. Additionally, there were also some important events experienced during the 64 years of Sultan Ibrahim's reign including World War I, World War II, and the arrival of the Japanese Army. In 1905, he set up a volunteer force called the Johor Volunteer Force (JVF) which was open to the public, especially members of the civil service. The establishment of JVF was to train and discipline the Johor Malays and give people the opportunity to join JVF to train their skills in using weapons in preparation for maintaining the state security.

As a result of the expansion efforts, the strength of JMF in 1913 was a total of 271 members of which 171 people were placed in the district of Johor Bahru and 100 in Muar. The number of members in 1914 increased to 396. All the JMF members were given military training and for those who could speak English were trained to learn signals and telegraphs. The coach was borrowed from the British Army Headquarters in Singapore. Therefore, apart from the Infantry Unit, Cannon Unit, Band Unit, and the Volunteer team, the State of Johor also seemed to have its own signal team. In an effort to increase the efficiency and ability of the armed forces, shooting contests were often held among them as well as with the British soldiers who occupied the Malay Peninsula and Singapore. War exercises were also often held together with the British army.

The first world war began in July 1914. The British captured and detained the Germans at Tanglin, Singapore. British enlisted the help of the JMF led by Captain Claymore and Captain Abdul Jabar to control the German prisoners because they did not trust the Indian soldiers, namely the 5th Light Indian Infantry. On 15 February 1915 , the Indian soldiers rioted by firing on Johor soldiers and releasing the German prisoners. A total of 50 Indian soldiers fled towards Johor near the Kota Tinggi district but were broken and detained by the JMF forces. The British appreciated the Johor Government's assistance. The British enlisted the help of the JMF forces again to control security on the 'Berani Island' and the 'Balik Mati Island' until the end of the war in Europe in 1918.

Sultan Ibrahim also created a law on the conditions of services in the JMF known as Law Number 18 in 1915. On 15 December 1915, the law was recorded in the Government Gazette. This law was spelled and printed in Jawi letters. Among the things enshrined in the law were the interpretation of terms such as Commander, Marshall Court, enemy, and more. The law was complete which made the JMF a military institution. This was because they could fulfill the clauses in the service such as recruitment, officer duties, discipline, offenses, and others. With this law, JMF could be better managed and administered and more controlled.

In 1938, the JMF team underwent a change in its organizational structure. That is, the British General of Commanding (GOC) proposed the appointment of a Training Director (Military Instructor) whose job was to organize and monitor the training of the JMF and JVF members to achieve efficiency by paying more attention to officers. On September 3, 1939, British declared war on Germany and its allies including Japan when Hitler invaded and conquered Poland. At that time, Sultan Ibrahim visited Germany for his health reasons. As a result of this war, he was detained for more than two years in London. However, with the help and control of the British government, he was able to return home in early 1941. During the Second World War, he organized the JMF and Volunteer Forces by increasing the number of troops. He also sent three cadet officers, namely Tan Sri Ibrahim Ismail, Tun Hussein Onn, and Ungku Ahmad bin Abdul Rahman to attend the Second Group Cadet Officer course at the Dehra Dun Military Officers Academy, India on 19th July 1941 to fight with the British army in Europe. 
Other members were given further training by the British military officers from Singapore. In this emergency situation, Sultan Ibrahim was asked to be the Major General for his two teams, namely the JMF and JVF. At that time, the total number of these two teams was estimated to be about 2000 people. The work scope of these members was expanded and sent to the districts.

The invasion of the Japanese forces in Malaya began in Kota Bharu, Kelantan, on December 8, 1941. The JMF was ready to defend the Japanese arrival in Kluang, Segamat, and even Mersing. However, the JMF defense at that time was not as strong as expected. On 28th January 1942, on the advice of British, Sultan Ibrahim was suggested to dissolve the JMF and JVF. This proposal was well received by Sultan Ibrahim and all the weapons were handed over to the British soldiers so as not to be captured by the enemy. British soldiers were also preparing to retreat to Singapore while all the members of the JMF and JVF were asked to take refuge in a safe place with their families.

After the end of World War II, the British wanted to change the existing status quo by introducing the Constitution of the Malayan Union. The idea was opposed by the rulers and the Malay people. On February 1, 1948, a new constitution named the Federation of Malaya was declared. The condition of the constitution was that the Federation of Malaya must only have one army at the federal level to defend the country's sovereignty. Therefore, the role of the JMF was reduced to focus on safeguarding the safety of the Sultan of Johor and his assets and the strength of these members was limited to only about 100 people. The team was given a new name, Sultan Own Body Guard. However, Sultan Ibrahim disagreed with the name and wanted the JMF name to be maintained. His proposal was well received by the British. Sultan Ibrahim also took over as JMF government. The role of the JMF as the security guards of the Sultan of Johor and the palace remains to this day. Sultan Ibrahim died on 8 May 1959 at the age of 85 .

\subsection{Era of Sultan Ismail Ibni Sultan Ibrahim (1959-1981)}

He was born on 28 October 1894 at Istana Semayam, Johor Bahru, Johor. He ruled the state of Johor for 22 years from 8 May 1959 to 10 May 1981. His coronation ceremony was held on 10 February 1960. During Sultan Ismail's reign, the JMF was no longer involved in military activities except for training purposes only. The role of the JMF team was more focused on the customary events at the palace but still had close ties with other military forces and was involved in military events such as shooting skills competitions. On 17 August 1981, the JMF team demonstrated their skills in the Gun Shooting Competition in Pulada and won the championship in the competition, defeating the New Zealand army. The band unit was reactivated on 16 April 1979 with the involvement of 33 members. The band also held weekly performances to the public at Taman Istana near Istana Besar Johor Bahru. In terms of the JMF management and administration affairs, this team also has its own building which is tightly controlled by the team complete with special uniforms while on duty. Customary events such as the opening ceremonies of the State Legislative Assembly, Coronation Ceremonies, and others are also maintained to date. Sultan Ismail died on 10 May 1981 at the age of 85.

\subsection{Era of Sultan Iskandar Ibni Sultan Ismail (1981-2010)}

Sultan Iskandar was born on April 8, 1932 at Istana Semayam, Johor Bahru, Johor. He ruled the state of Johor for 29 years from 11 May 1981 to 22 January 2010. During that period, he held the position of Yang Di-Pertuan Agong Malaysia from 26 April 1984 to 25 April 1989. The role and duties of the JMF team carried out by his father were also still maintained and continued. He was very firm in carrying out his responsibilities as a Sultan as well as the Yang Di-Pertuan Agong (Nelson, 2007). His assertiveness and other issues that occurred in the 1990s were disliked by some which led to various negative speculations from some communities towards him and the JMF (Kershaw, 2001) until the issue of his dissolution arose. The JMF Bill of Dissolution was made in Parliament to reduce the immunity of the Malay Rulers. However, on the legal advice of legal practitioners, this team was not dissolved and continues to be maintained until today. Sultan Iskandar died on 22 January 2010 at the age of 77.

\subsection{Era of Sultan Ibrahim Ibni Sultan Iskandar (2010-present)}

Sultan Ibrahim was born on 22 November 1958 at the Sultanah Aminah Hospital, Johor Bahru, Johor. His reign began from January 23, 2010 until now, which is more than 10 years. His coronation ceremony was held on 23 March 2015 at the Istana Besar Johor Bahru. The role and responsibilities of the JMF during his reign are still the same. Sultan Ibrahim managed to rebuild a positive perception among the people and the support of the federal government for the retention of this team.

During his reign until now, many reforms have been made to the JMF. Among the reforms was the creation of a new camp that is modern and more comfortable for the JMF. The Sultan Ibrahim Camp is built on an area of 20.8 hectares near Istana Bukit Serene located at Jalan Tasik, Johor Bahru. The organizational structure and Service Scheme of the JMF team members were also reviewed for improvement and approved at the federal level. The management of the staffing and financial administration services of JMF which was previously under the supervision of the Johor Royal Department was also handed over to a new department under the name of the 'Timbalan Setia Negeri' Department. The administrative management and financial affairs of this team were further strengthened by the presence of civil servants led by the Johor State Administrative Officer as the Controlling Officer (Finance). However, the administration of the JMF operations is still under the control of the JMF members themselves. The Commanding Officer for the JMF currently is Tunku Mahkota of Johor and assisted by the second comander with a Major rank. All administrative matters of the JMF must be approved by the Commanding Officer first. 
Sultan Ibrahim also ordered an Elite Special Unit to be set up following the strike in Perak. This unit needed to undergo training that was equivalent to the Special Operations Unit of the Malaysian Armed Forces Command. Currently, the total strength of the JMF team members including civil servants is 425 people. Sultan Ibrahim also ordered that the Commission of JMF be established to manage the appointment of JMF members. JMF also received recognition from the international media with the publication of a special documentary on the history and role of the JMF team through the 'History Channel'. This has indirectly introduced the JMF team internationally as an institution that has its own historical value.

\section{Results and Finding}

Digital media through the 'History Channel' was also collected and analyzed to achieve the objectives of this study.

Table 1: Interview of Commander (Sultan of Johor) and Government Officer (Tunku Mahkota Johor TMJ) in 'History Channel'

Duration Documentary Dialogue Summary

$00.00-$

01.10
The only royal guard in Malaysia and the oldest army in the country.

Sultan Johore: JMF rules now have change. They are guarding some Johore palaces Sultan Johore: And we have to change it to accommodate with time.

They play an important role in all royal ceremony. Some of them have been transform into a Elite Force

TMJ: It should be a tips of the sphere in Johore Military Forces.

As commanding officer, the crown price leads from the front

TMJ: had to sacrifice myself and said 'look, pain is temporary, but victories forever'

Chosen for the physical and military abilities, train to guard and protect the devotion of the Sultan is beyond now. This are the Johore Military Forces, the most distinctive and unique army in Malaysia
At this duration, it can be concluded that:

JMF is the oldest and unique military force in Malaysia that needs to preserve its historical heritage.

However, the role and rules of the JMF change with the changing times.

Now, JMF is more focused on customs such as ceremonies involving royal ceremonies and training and protecting the Sultan.
02.54

04.11
The JMF was formed by 1886 . It's the time of prediction was expending control in Malaya peninsula. Driving by the economic boom in the west. Regionally, the French capturing Indo-China threaten the floreshing treat of the street salaman. To guarantee his state independent, Johor's ruler, Sultan Abu Bakar signed an agreement with the British's government.

Sultan Johore: Johor wants to be it own nation at that time. And it was recognised by the British. That's how JMF started.

The agreement recognised Johore as a several land under the rule of Sultan Abu Bakar including the establishment of the military forces to work together with the police.

Francis Hutchinson: Sultan Abu Bakar wanted to have arm force to secure the border and maintain
At this duration, it can be concluded that:

JMF was established after a Loyal Agreement between the Johor government and the British.

JMF works with the police to maintain state security.

JMF is the oldest military force in Malaysia and is a legacy that needs to be preserved. 
into a piece. Also he wanted to have that to preclude the British from coming in.

With the foundation lay by Sultan Abu Bakar, the JMF today is unique and independent military organization with distinction of being the oldest army in Malaysia.

TMJ: The Johore Military Force play a big part in terms of reminding of Johorean of where we come from, what is our history and what should we preserve in term of our heritage.

\section{Discussion}

Before the independence of Malaya, in the era of the first Modern Johor Sultanate of Sultan Abu Bakar, the establishment of JMF was more focused to defend the sovereignty and security of the state. This is because to recognize the sovereignty of a state, a king must have influence and members of his own security as a symbol of a king who provides protection to the people. The basic construction of a country must have elements such as government, sovereignty, people, land, and even borders. With the presence of the JMF forces, the king's influence and sovereignty will be stronger as a protector to his people to be more confident under the auspice of his rule. During the reign of Sultan Ibrahim, JMF was trained to be an efficient military force. Training was given to the members, but it took time to ensure the members were fully prepared for any battle. However, when the JMF failed to defend the state from the sudden invasion of the Japanese army in Malaya, the JMF was disbanded for a while under the advice of the British army. After Japan surrendered, and after the consolidation of the Malay states in the Federation of Malaya, the role of team JMF was reduced to be the Sultan's bodyguards and customary soldiers until now.

After independence, in the eras of Sultan Ismail, Sultan Iskandar, and Sultan Ibrahim, the JMF was only focused on customary events in the Johor palace and the security of the Sultan and his assets. Customs in every state in Malaysia are different. In Johor, practicing the Temenggong Customs in any customary events such as the Coronation Ceremony, Opening Ceremony of the State Legislative Assembly, and others have been inherited for generations since the rule of the first Modern Johor Sultanate and are maintained until now. The coronation ceremony or crowning of the King is conducted when the new throne rises. After the appointment is made, the coronation ceremony conducted as a symbol of dignifying the King at a higher level reflects the wealth of customs, culture, and identity of the country (Shamrahayu, 2020).

Apart from that, one of the traditions that only exists in Johor is the brass band. In Johor, there is no Royal Nobat that plays Nobat Songs when the King leaves or arrives at the palace, the Coronation Ceremony (Official Website of Istana Negara, 2020) and so on, but the song "Allah Selamatkan Sultan" is played by the JMF Band. It also shows that the institution of the King can also be defined as a warehouse that brings together traditions and ensures continuity of customs and ceremonies from time immemorial. The existence of a monarchical institution is a symbol of the strength and sovereignty of a country as well as having a respected position and degree to take a decision that is important for the interests of his country.

JMF has existed for more than a century when it was established even before Malaya achieved its independence and had its own military force. The role of JMF had undergone various changes over time according to the administration of the Sultanate of Modern Johor. The establishment, development, downsizing, and improvement of the strength of this team were also constantly refined from time to time according to the needs of its current function in line with the legislation at the federal and state levels of Johor. Although this team has reached the age of 135, the challenge that JMF must face in this era is to ensure the existence of this team to the people, especially the people of Johor on the sovereignty of the King and preserving the historical value of JMF as commanded by Sultan Ibrahim Ibni Sultan Iskandar. The JMF is one of the sources of pride in the state of Johor and holds an important place in history.

\section{Conclusion and Recommendation}

The uniform worn on the body and the rank pinned to the shoulder are not a mere pride. It is a trust that must be borne with partriotism. JMF is also one of the difficult and dangerous jobs because their need to protect the Sultan's life comes first before themselves. They must be willing to sacrifice their lives and time to defend the sovereignty of the King in the state of Johor. The existence of this team needs to be preserved to ensure the preservation of its historical value. A comprehensive study of this team also needs to be conducted to identify the uniqueness and relevance of this team to the state and federal sovereignty. With this, it is hoped that the results of this study can help the public to be more aware of the historical values of the JMF and know its role under the different eras of the Sultanate of Modern Johor since its establishment until now. In conclusion, the JMF team should be maintained because it is one of the privileges for the state of Johor and is the only state in Malaysia to have its own state army heritage and holds a unique historical value in the world. 


\section{References}

1. Abdul Aziz Bari (2002). Majlis Raja-Raja: Kedudukan dan Peranan dalam Perlembagaan Malaysia. Dewan Bahasa dan Pustaka Kuala Lumpur.

2. Abdul Rahim Ramli (2018). JDT Johor Darul Ta'zim An Abode of Dignity. Penerbit UTM Press. Universiti Teknologi Malaysia. Skudai. Johor Bahru.

3. Bharuddin Che Pa, Farizah Zulkafli (2016). The Separation of Power Between Western and Islamic Perspective: The Application in Malaysia. Shariah Journal, Vol. 22, No. 1 (2014) 21-56

4. Damon Sajnani (2015). Remembering Monarchy, Forgetting Coloniality: The Elision of Race in Canadian Monarchy Abolition Debates. Canadian Ethnic Studies Association. Canadian Ethnic Studies, Volume 47, Number 2, 2015, pp. 137-163 (Article); DOI: 10.1353/ces.2015.0014

5. Duncan McCargo (2005). Network monarchy and legitimacy crises in Thailand. The Pacific Review, 18:4, 499-519; DOI: 10.1080/09512740500338937 http://dx.doi.org/ 10.1080/09512740500338937

6. Exhibition material of Royal Abu Bakar Museum (2016). Bahan Pameran Sempena Perasmian Kem Askar Sultan Ibrahim. Royal Abu Bakar Museum, Johor Bahru, Johor.

7. Exhibition material of Royal Malaysia Police Museum (2019). Royal Malaysia Police Museum, Bukit Kepong, Pagoh, Muar.

8. Exhibition material of Royal Abu Bakar Museum (1986). Program Book: Ceremony for The Exchange of Royal Johor Military Force Banners by His Majesty Sultan Iskandar Yang Di-Pertuan Agong. Royal Abu Bakar Museum, Johor Bahru.

9. Institut of Historical Research (2019). Website The History of Parliament; British Politicial, Social \& Local History. Retrieved 20 Jun 2020. http://www.histparl.ac.uk/research

10. Laman Web Rasmi Istana Negara (2020). Nobat Diraja. Retrieved November 7, 2020, from http://pengurusan.istananegara.gov.my/index.php?option $=$ com_content\&view $=$ article\&id=104:nobatdiraja\&catid $=91 \&$ Itemid $=582$

11. M. A. Fawzi Mohd. Basri (1988). Johor, 1855-1917: Pentadbiran dan perkembangannya. Kuala Lumpur: Fajar Bakti.

12. Nelson Benjamin (2007). Inspiring ruler. The Star. Retrieved November 7, 2020, from https://www.thestar.com.my/news/nation/2007/04/08/inspiring-ruler

13. Ong Guan Sai (2016). Institusi beraja pelindung, penyatu rakyat. BH Online bertarikh 14 Disember 2016. Diakses pada 18 Mei 2020. https://www.bharian.com.my/node/223589

14. Ramlah Adam, Wan Ahmad Fauzi Wan Husain (2017). Uniknya Sitem Pemerintahan Beraja Malaysia, Mari Baca dan Ketahuinya. FMT News bertarikh 23 April 2017. Diakses pada 29 Jun 2020 https://www.freemalaysiatoday.com/category/leisure/2017/04/23/uniknya-sistem-pemerintahan-berajamalaysia-mari-baca-dan-ketahuinya/

15. Roger Kershaw (2001). Monarchy in South-East Asia: The Faces of Tradition in Transition. Politics in Asia series. London: Routledge, 102-3.

16. Shamrahayu Abd Aziz (2019). Istiadat pertabalan lambang maruah negara. BH Online bertarikh 19 Julai 2019. Diakses pada 17 Mei 2020. https://www.bharian.com.my/berita/nasional/2019/07/586738/istiadatpertabalan-lambang-maruah-negara

17. Shaharom Husain (1995). Sejarah Johor Kaitannya Dengan Negeri Melayu. Kuala Lumpur: Fajar Bakti.

18. Tun Suzana Tun Othman (2002). Institusi Bendahara: permata Melayu yang hilang, dinasti Bendahara Johor-Pahang. Kuala Lumpur: Pustaka BSM.

19. National Film Development Corporation Malaysia, Finas (2015). Askar Timbalan Setia Negeri Johor: Lambang Kebesaran dan Kebanggan. Deraf Dokumentari. Unit Penyelidikan, Muzium DiRaja Abu Bakar, Istana Besar Johor, Johor Bahru.

20. Sultan Ibrahim Sultan Iskandar (2016). The Royal Johor Military Force (JMF) - the oldest military unit in the country has a new base. Official Facebook. Retrieved November 7, 2020, from https://www.facebook.com/officialsultanibrahim/posts/the-royal-johor-military-force-jmf-the-oldestmilitary-unit-in-the-country-has-a/572126419620722/ 